Agro-Science Journal of Tropical Agriculture, Food, Environment and Extension Volume 8 Number 1 January 2009 pp. $60-65$

TSSN 1119-7455

\title{
CHANGES IN SOIL PROPERTIES UNDER ALLEY CROPPING SYSTEM OF THREE LEGUMINOUS CROPS
}

\author{
Okonkwo C. I. ${ }^{1}$, Mbagwu J. S. C. ${ }^{2}$ and Egwu S. O. ${ }^{1}$ \\ ${ }^{1}$ Dept of Soil and Environment Management, Ebonyi State University, Abakaliki., Nigeria \\ ${ }^{2}$ Dept of Soil Science, University of Nigeria, Nsukka, Nigeria
}

\begin{abstract}
A study to evaluate the changes in soil properties, under existing alley cropping system with three leguminous crops (Leucaena leucocephala, Gliricidia sepium, and Cajanus cajan) was conducted in the experimental farm of the Faculty of Agriculture and Natural Resources Management, Ebonyi State University, Abakaliki between 2003-2005. The study was established in a randomized complete block design with five treatments consisting of $10 \mathrm{t} \mathrm{ha}^{-1}$ each of L. leucocephala, G. sepium and C. cajan prunings, 300kg ha-1 of 20:10:10 and a control with no amendments. The study was replicated four times. Soil pH increased from $\mathrm{pH} 4.2$ (strongly acid) in the pre-planting to $\mathrm{pH} 6.1$ (slightly acid) in C. cajan alley plots. The organic matter increased from $1.01 \mathrm{~g} \mathrm{~kg}^{-1}$ in the pre-planting to $5.98 \mathrm{~g} \mathrm{~kg}^{-1}$ in the C. cajan alley plots in 2005. Total $N$ increased in all the alley plots with the highest $N$ content of $2.31 \mathrm{~g} \mathrm{~kg}^{-1}$ in the G. sepium alley plots, which was $68 \%$ in $2003,90 \%$ in 2004 and $95 \%$ in 2005 over the pre-planting. Available $P$ and exchangeable Ca and Mg increased significantly $(p<0.05)$ in the alley plots over the pre-planting. The ECEC increased in line with exchangeable bases. Total acidity and $A l^{3+}$ saturation were very low in the alley plots.
\end{abstract}

Key words: Alley cropping, hedgerow, Cajanus cajan, Gliricidia sepium, Leucaena leucocephala

\section{INTRODUCTION}

One of the crucial factors for the success of improved farming system is efficient recycling of organic materials. This exploits the biological possibility, which is an essential factor in agroforestry systems, that aims primarily at a compromise between continuous cropping and long fallow periods (Kang and Duguma, 1985). Since farmers in the developing countries of the tropics are predominantly resource poor and can hardly afford costly inputs, it is necessary to develop low input soil management technologies that can restore and sustain crop production. Improved and new technologies, designed as alternatives to the shifting cultivation and bush fallow systems, must include systems or mechanisms that can replenish the soil organic matter (Young, 1989).

Investigations were carried out at the International Institute of Tropical Agriculture (IITA), Ibadan, Nigeria, to assess the potentials of intercropping woody species with food crops, as a land use system to manage fragile uplands, dominated by low-active clay soils, for continuous crop production, in the humid and sub-humid zone and to improve the traditional bush-fallow, slashand-burn, cultivation system (Lal and Greenland, 1986). This led to the development of and research on the alley cropping system (Kang et al., 1990).
Alley cropping is an agroforestry system, similar in approach to contour hedgerow system, in which food crops are grown in alleys formed by hedgerows of trees and shrubs that are usually fast growing legumes, which enrich the soil through symbiotic nitrogen fixation and recycle nutrients from the soil (Kang and Wilson, 1987). The hedgerows are cut back at planting and periodically pruned during cropping, to prevent shading and to reduce competition with the associated crops. The hedgerows are allowed to grow freely to cover the land when there is no corps (Kang et al., 1990).

The objective of this study was to assess the changes in soil properties under alley cropping system with three leguminous crops.

\section{MATERIALS AND METHODS}

This study was carried out in an existing alley cropping system established in 1991, in the experimental filed of the Faculty of Agriculture and natural Resources Management, Ebonyi State University, Abakaliki, Southeast Nigeria. Abakaliki lies on latitude $06^{0} 04^{1} \mathrm{~N}$ and longitude $18^{0} 65^{1} \mathrm{E}$ Southeast of the derived Savanna Zone of Nigeria. Typical of the humid tropics, it has a pseudobimodal rainfall pattern from April to November. Total rainfall in the area ranges between 1,500$2,000 \mathrm{~mm}$, with a mean of $1,800 \mathrm{~mm}$ and sometimes 
in form of violent shower of short duration. Rainfall is seasonal and defines the farming seasons (ODNRI, 1989). The area is characterized by high temperature with maximum mean daily temperature of $27-31^{\circ} \mathrm{C}$ throughout the year. Humidity is high with lowest levels in April just before the on-set of the rainy season.

Abakaliki agricultural zone lies within Asu river group and consists of olive-brown, sandy shale, fine-grained sand stones and mudstone. The soil is shallow with unconsolidated parent materials (Shale residuum) within $1 \mathrm{~m}$ of the soil surface. (Anikwe et al., 2000). It belongs to the order Ultisol within Ezzamgbo soil association and is classified as typic Haplustult (FDALR, 1985).

\section{Experimental Design}

The experiment was established in a randomized complete block design (RCBD), with five treatments and four replications. The treatments were as follow:

$10 \mathrm{t} \mathrm{ha}^{-1}$ Leuceana pruning,

$10 \mathrm{tha}^{-1}$ of Gliricidia pruning

$10 \mathrm{tha}^{-1}$ of Cajanus pruning,

$300 \mathrm{~kg} \mathrm{ha}^{-1}$ of NPK fertilizer,

Control (no pruning, and no fertilizer)

\section{Soil Sampling and Analysis}

The soils were sampled prior to the application of pruning. Soil samples were collected randomly in each plot with a soil augar from a depth of $0-20 \mathrm{~cm}$. The soil samples were air-dried at room temperature and passed through a $2 \mathrm{~mm}$ sieve. Composite soils sample was achieved using the coning and quartering method. Mechanical analysis was carried out using the hydrometer method described by Bouyoucos (1962) and applying sodium hexametaphoshate as the dispersant. Soil sample was analyzed for $\mathrm{pH}$ in 1:2.5 soil-water ratio. Total organic carbon was determined using an improved chromic acid digestion and spectophotometric method (Heanes, 1984) and organic matter was obtained by multiplying the organic carbon by 1.724 . Available phosphorus was determined using the Bray-2 procedure (Olsen and Sommer, 1951); total nitrogen was analyzed using the modified Kjeldahl procedure described by Bremner and Mulvaney (1982); exchangeable potassium and calcium were determined using the method described by Jou (1983). Magnesium was assessed using the methodology developed by Tel and Rao (1982). Total exchangeable acidity (TEA) was determined by the KCL extraction method (Tel and Rao, 1982). Effective cation exchange capacity (ECEC) was obtained by the summation method. ECEC $=$ TEB + TEA; where TEB is Total Exchange base. Apart from the pre-planting soil analysis, further soil sampling and analysis were carried out at the end of the planting seasons of 2003-2005. The test crop grown in the alley plots was maize Oba Supper II. Data obtained from this study were analyzed using the Statistical Analysis Systems (SAS, 1985).

\section{RESULTS AND DISCUSSION \\ Pre-planting soil properties.}

Table 1 showed the properties of the top soil $(0-20 \mathrm{~cm})$ of the study site at the start of the experiment. The textural class was sandy loam. The $\mathrm{pH}$ of the soil was low $(\mathrm{pH} 4.2)$ According to the USDA- SCS (1974) rating the soil was extremely acidic. The organic matter, total $\mathrm{N}$ and available $\mathrm{P}$ were low according to the classification of Landon (1991) and Enwezor (1989). Although $\mathrm{Ca}$ and $\mathrm{Mg}$ were within the minimum deficiency threshold for crop establishment in the tropics (Landon, 1991), they did not affect any change in both soil $\mathrm{pH}$ and soil $\mathrm{P}$. The low $\mathrm{K}$ and ECEC observed in this study could be due to low levels of both organic matter and percent clay. This showed that the soils of the study site had low nutrient reserve, since both ECEC and organic matter were widely used as indicators of soil fertility.

\section{Post-Harvest Soil Properties.}

The results of the Post-harvest soil properties are shown in Table 2. There was no change in the soil texture. Changes in the soil chemical properties were observed in the last two years of study (2004-2005) over the pre-planting soil result. The $\mathrm{pH}$ values in the $C$. cajan alley plots increased significantly $(\mathrm{P}<0.05)$ over all the other treatments. While the soil $\mathrm{pH}$ in the preplanting was extremely acidic ( $\mathrm{pH} \mathrm{4.2),} \mathrm{in} 2004$ it became moderately acidic ( $\mathrm{pH} 5.8$ ) and was slightly acid $(\mathrm{pH} \mathrm{6.1)}$ in 2005. The increase in $\mathrm{pH}$ values in all the alley plots could be due to the decomposition of the incorporated materials from pruning. In the fertilizer plots, $\mathrm{pH}$ remained extremely acidic in 2004 and 2005. The increased $\mathrm{pH}$ values obtained in the alley plots showed a change in a positive direction when compared with $\mathrm{pH}$ values of both the pre-planting and the fertilizer plots.

The organic matter increased with time in all the treatments, from $1.01 \mathrm{~g} \mathrm{~kg}^{-1}$ in the preplanting to $5.98 \mathrm{~g} \mathrm{~kg}^{-1}$ in the C. cajan alley plots. In 2005, the soil organic matter content from the $C$. cajan plots, was significantly different $(\mathrm{P}<0.05)$ from L. leucocephala, fertilized and control plots. The soil organic matter obtained in the alley plots would be rated high in accordance to Landon (1991), while that from the fertilized and control plots would be rated low. The result obtained in this study agreed with the report of Atta-Krah (1986), that soils under alley cropping system were 
Okonkwo C. I., Mbagwu J. S. C. and Egwua S. O.

higher in organic matter and $\mathrm{N}$ than soils without hedgerow tree. Total nitrogen $(\mathrm{N})$ increased in the alley plots over time with continuous addition of pruning from the hedgerow trees. The highest $\mathrm{N}$ content of $2.31 \mathrm{~g} \mathrm{~kg}^{-1}$ was obtained in the $G$. sepium alley plots in the year 2005. The control plots were very low in $\mathrm{N}\left(0.29 \mathrm{~g} \mathrm{~N} \mathrm{~kg}^{-1}\right)$ in the same sampling year (2005). Both L. leucocephala and C. cajan had $\mathrm{N}$ values ranging from $0.52 \mathrm{~g} \mathrm{~N} \mathrm{~kg}^{-1}$ for $L$. leucocephala in 2003 to $1.83 \mathrm{~g} \mathrm{~N} \mathrm{~kg}^{-1}$ in 2005 , and $0.49 \mathrm{~g} \mathrm{~N} \mathrm{~kg}^{1-}$ for C. cajan in 2003 to $1.44 \mathrm{~N} \mathrm{~kg}^{-1}$ in 2005

Table 1. Pre-Planting Soil physical and chemical properties $(0-20 \mathrm{~cm})$

\begin{tabular}{ll}
\hline Sand \% & 61 \\
Silt \% & 27 \\
Clay \% & 12 \\
Texture & Sandy Loam \\
$\mathrm{Ph}\left(\mathrm{H}_{2} 0\right)$ & 4.2 \\
$\mathrm{OM} \mathrm{g} \mathrm{kg}^{-1}$ & 1.01 \\
$\mathrm{~N} \mathrm{~g} \mathrm{~kg}$ & 0.12 \\
$\mathrm{P}\left(\mathrm{mgkg}^{-1}\right)$ & 10.13 \\
$\mathrm{Ca}\left(\mathrm{c} \mathrm{mol} \mathrm{kg}^{-1}\right)$ & 2.40 \\
$\mathrm{Mg}(\mathrm{c} \mathrm{mol} \mathrm{kg}$ & 0.47 \\
$\mathrm{~K}(\mathrm{c} \mathrm{mol} \mathrm{kg})$ & 0.19 \\
Total Acidity $(\mathrm{c} \mathrm{mol} \mathrm{kg}$ & 3.21 \\
ECEC $(\mathrm{c} \mathrm{mol} \mathrm{kg})$ & 6.27 \\
\hline
\end{tabular}

TABLE 2. Post-plating soil physical and chemical properties $(0-20 \mathrm{~cm})$

\begin{tabular}{|c|c|c|c|c|c|c|c|c|c|c|c|c|c|c|c|c|}
\hline Treatments & Sand & Silt & Clay & & $\mathrm{pH}$ & $\begin{array}{l}\mathrm{Om} \\
\mathrm{gkg}^{-1}\end{array}$ & $\begin{array}{l}\mathrm{N} \\
\mathrm{gkg}^{-1}\end{array}$ & $\begin{array}{l}\mathrm{P}^{1} \\
\mathrm{mgkg}\end{array}$ & $\mathrm{K}$ & $\mathrm{Mg}$ & $\mathrm{Ca}$ & $\begin{array}{l}\text { CEC } \\
\text { cmolkg-1 }\end{array}$ & TEA & Exch $\mathrm{Al}^{3+}$ & ECEC & $\mathrm{Al}^{3} \mathrm{Sat}$ \\
\hline & & $\%$ & & Text. & $\mathrm{H}_{2} \mathrm{O}$ & 2003 & & & & & & & & & & \\
\hline Leucaena & 62 & 26 & $\overline{12}$ & SL & 4.6 & 2.64 & 0.52 & 14.34 & 0.28 & 2.80 & 2.64 & 5.72 & 2.83 & 2.74 & 8.65 & 31.68 \\
\hline Gliricidia & 61 & 25 & 14 & SL & 4.8 & 3.07 & 0.62 & 16.01 & 0.29 & 3.94 & 3.24 & 7.44 & 2.80 & 2.00 & 10.27 & 21.05 \\
\hline Cajanus & 62 & 25 & 13 & SL & 4.9 & 3.37 & 0.49 & 19.55 & 0.26 & 3.64 & 2.80 & 6.70 & 2.96 & 1.73 & 9.50 & 17.37 \\
\hline $\begin{array}{l}300 \mathrm{Kg} \quad \mathrm{ha}^{-1} \\
\text { NPK }\end{array}$ & 62 & 26 & 12 & SL & 4.3 & 2.24 & 0.35 & 12.64 & 0.26 & 2.71 & 2.34 & 5.31 & 3.84 & 3.16 & 9.15 & 34.45 \\
\hline Control & 64 & 26 & 10 & SL & 4.5 & 1.80 & 0.14 & 10.94 & 0.12 & 2.01 & 1.98 & 4.11 & 3.03 & 2.98 & 7.14 & 42.33 \\
\hline LSD (0.05) & NS & NS & SN & & SN & 0.21 & 0.07 & 2.01 & 0.02 & NS & 0.22 & 1.37 & 0.31 & 0.21 & NS & 6.43 \\
\hline & & & & & & 2004 & & & & & & & & & & \\
\hline Leucaena & 61 & 24 & 15 & SL & 5.5 & 3.17 & 1.08 & 19.58 & 0.31 & 3.24 & 3.15 & 6.70 & 2.96 & 1.68 & 9.66 & 17.39 \\
\hline Giliricidia & 59 & 24 & 17 & SL & 5.7 & 3.83 & 1.13 & 20.50 & 0.30 & 4.73 & 4.25 & 9.28 & 2.98 & 1.46 & 12.26 & 9.77 \\
\hline Cajanus & 59 & 23 & 18 & SL & 5.8 & 4.36 & 1.05 & 26.90 & 0.29 & 5.05 & 4.08 & 9,42 & 2.64 & 1.18 & 12.06 & 11.93 \\
\hline $\begin{array}{l}300 \mathrm{Kg} \\
{ }^{1} \mathrm{NPK}\end{array}$ & 61 & 25 & 14 & SL & 4.2 & 2.88 & 0.51 & 17.20 & 0.30 & 4.64 & 2.94 & 7.88 & 3.90 & 2.87 & 11.78 & 35.83 \\
\hline Control & 62 & 25 & 13 & SL & 4.7 & 2.28 & 0.16 & 12.80 & 0.19 & 2.47 & 2.36 & 5.02 & 2.92 & 2.61 & 7.94 & 33.29 \\
\hline $\operatorname{LSD}(0.05)$ & NS & NS & SN & & 0.09 & 1.06 & 0.14 & 2.04 & 0.03 & 0.91 & 0.47 & 2.86 & 0.18 & 0.47 & 1.75 & 3.78 \\
\hline & 62 & 23 & & SI & 58 & 2005 & 184 & 2347 & 042 & & 520 & 1043 & 284 & 135 & 1327 & 0.80 \\
\hline Giliricidia & $\begin{array}{l}02 \\
60\end{array}$ & $\begin{array}{l}23 \\
22\end{array}$ & $\begin{array}{l}15 \\
18\end{array}$ & $\begin{array}{l}\mathrm{SL} \\
\mathrm{SL}\end{array}$ & $\begin{array}{l}5.8 \\
5.9\end{array}$ & $\begin{array}{l}4.10 \\
5.02\end{array}$ & $\begin{array}{l}1.84 \\
2.31\end{array}$ & $\begin{array}{l}25.41 \\
28.82\end{array}$ & $\begin{array}{l}0.42 \\
0.37\end{array}$ & $\begin{array}{l}4.81 \\
5.23\end{array}$ & $\begin{array}{l}5.20 \\
6.40\end{array}$ & $\begin{array}{l}10.45 \\
12.00\end{array}$ & $\begin{array}{l}2.84 \\
2.13\end{array}$ & 1.08 & 14.13 & 7.67 \\
\hline Cajanus & 61 & 20 & 19 & SL & 6.1 & 5.98 & 1.44 & 32.61 & 0.32 & 5.56 & 7.20 & 13.08 & 2.07 & 0.92 & 15.15 & 6.05 \\
\hline $\begin{array}{l}300 \mathrm{Kg} \quad \mathrm{ha}^{-1} \\
\text { NPK }\end{array}$ & 62 & 24 & 14 & SL & 4.1 & 3.05 & 0.94 & 19.42 & 0.33 & 5.01 & 3.80 & 9.14 & 4.13 & 3.98 & 13.27 & 29.99 \\
\hline Control & 62 & 25 & 13 & SL & 4.9 & 2.64 & 0.29 & 14.60 & 0.14 & 3.26 & 2.91 & 6.31 & 3.34 & 3.04 & 9.65 & 31.50 \\
\hline $\operatorname{LSD}(0.05)$ & NS & NS & NS & & 0.13 & 1.36 & 0.47 & 3.35 & 0.05 & 1.03 & 1.43 & 3.17 & 1.15 & 0.63 & 1.91 & 2.99 \\
\hline
\end{tabular}

Text $=$ texture, $\mathrm{SL}=$ Sandy Loam, $\mathrm{OM}=$ Organic matter, Sat $=$ Saturation, $\mathrm{NS}=$ Non significant 
However, the fertilized plots had total soil $\mathrm{N}$ content of 0.35 to $0.94 \mathrm{~g} \mathrm{~N} \mathrm{~kg}^{-1}$ in the same period of study. Despite plant uptake of $\mathrm{N}$, the total soil $\mathrm{N}$ from either $G$. sepium or L. leucocephala alley plots was significantly higher than the fertilized or the control plots. Comparing the soil $\mathrm{N}$ contents of the post-harvest in the G. sepium hedgerow plots with the pre-planting soil $\mathrm{N}$ for the period of study, it was observed that soil $\mathrm{N}$ increased by $68 \%$ in $2003,90 \%$ in 2004 and $95 \%$ in 2005 in the G. sepium hedgerow plots. While in the fertilizer post-harvest plots, the soil $\mathrm{N}$ increased by $48 \%$ in 2003, 62\% in 2004 and $76 \%$ in 2005 . This result therefore, showed that incorporated pruning of the legume hedgerows trees released more $\mathrm{N}$ to the soil than the fertilizer. The lower values of $\mathrm{N}$ obtained in the fertilized plots could be due to rate of release, uptake by crop or leaching. In the G. sepium hedgerow plots, like wise the other legumes in the alley cropping system, $\mathrm{N}$ could have been released slowly to the soil avoiding leaching process. Among the legumes in the alley cropping system, $\mathrm{N}$ in $G$. sepium plots was significantly different $(\mathrm{P}<0.05)$ to the $L$. leucocephala and C. cajan in 2003. But there was no significant difference in soil $\mathrm{N}$ between G. sepium and L. leucocephala in 2004 and 2005 cropping years. The results obtained in this study did not agree with the reports of Kang et al. (1990) and Gichuru and Kang (1990), who obtained higher $\mathrm{N}$ for $L$. leucocephala over $G$. sepium in their different studies. The low soil $\mathrm{N}$ obtained in the $L$. leucocephala alley plots could be due mainly to lower $\mathrm{pH}$ and incompatibility of native rhizobia species involved in symbiosis. Hutton (1990), stated that L. leucocephala grew poorly at $\mathrm{pH}$ less than 5.5, while G. sepium could tolerate higher soil acidity levels and grow at pH 4.6 (Duguma, 1983). Sanginga et al (1990) pointed out that there was great genetic variability among Leucaena species in $\mathrm{N}$ fixation because of low $\mathrm{pH}$ and specifically towards inocula of rhizobia species.

The available $\mathrm{P}$ in the pre-planting was rated low (10.3mg $\mathrm{Pkg}^{-1}$ ) based on Enwezor et al. (1989) and Landon (1991) ratings for P. This level was typical of the soils of humid tropical region. The levels of available $\mathrm{P}$ increased progressively more in the alley plots in the three years of study particularly in the $C$. cajan alley plots $\left(36.61 \mathrm{mg} \mathrm{P} \mathrm{kg}^{-1}\right.$ in 2005). Also $\mathrm{P}$ levels increased in both the fertilizer and control plots in comparison to the pre-planting soil $\mathrm{P}$. The available soil $\mathrm{P}$ in the $C$. cajan alley plots was significantly different $(\mathrm{P}<0.05)$ to the other treatments. The increased soil $\mathrm{P}$ in the alley plots of 2003-2005 could be attributed to $P$ from the pruning and changes in the soil pH. Larsen (1967) reported that maximum phosphate availability is obtained when the soil $\mathrm{pH}$ is maintained in the range from 6.0 to 7.0. Also it was observed that increase in soil $\mathrm{pH}$ in this study was followed correspondingly with decreased exchangeable $\mathrm{AI}^{3+}$ in the alley plots, hence the high available $\mathrm{P}$.

There were increased levels of exchangeable $\mathrm{K}, \mathrm{Mg}$ and $\mathrm{Ca}$ in both the alley and fertilized plots over the pre-planting soil result. The values of $\mathrm{K}$ obtained in the three year study in the control plots varied greatly with the other treatments. In 2003 and 2005, K values were lower than that obtained in the pre-planting but were equal to the later in 2004. The lower values in the 2003 and 2005 could be attributed to some reasons: first, it could be a result of crop uptake of K; secondly, leaching could have occurred and thirdly, there was no input to build up $\mathrm{K}$ in the control plots. Among all the treatments, $\mathrm{K}$ values also varied. In 2003, G. sepium alley plots had the highest levels of $\mathrm{K}\left(0.29 \mathrm{cmol} \mathrm{kg}^{-1}\right)$ but in 2004 and 2005, L. leucocephala alley plots had the highest $\mathrm{K}$ values of $0.31 \mathrm{c} \mathrm{mol} \mathrm{kg}^{-1}$ and $0.42 \mathrm{c} \mathrm{mol}$ $\mathrm{kg}^{-1}$ respectively. Based on Landon (1991) ratings $\mathrm{Mg}$ was high in the $G$. sepium and $C$. cajan plots (2003), higher in the G. sepium, C. cajan and fertilizer plots in 2004 but highest in all the alley and fertilizer plots in 2005. Exchangeable Ca was only high in the G. sepium and C. cajan in 2005. The increased exchangeable bases probably brought about increase in the soil pH. The ECEC levels increased above the pre-planting values in all the treatments of 2003-2005. In 2003 and 2004, the ECEC values were highest in the G. sepium plots and the increase over the pre-planting was $24 \%$ and $27 \%$ for the two years respectively. In 2005, C. cajan alley plots had the highest ECEC value of 15.15 cmol $\mathrm{kg}^{-1}$. This was $42 \%$ higher than the level obtained in the pre-planting. These results showed that the alley cropping system improved ECEC levels within the period of study more than any other treatments. The ECEC level in this work was a reflection of the organic matter content of the soil. Increase in the organic matter values in all treatments were correspondingly followed with increased ECEC.

Total exchangeable acidity decreased in all the alley plots compared with the pre-planting values. The lowest total exchangeable acidity of 2.07 c mol kg-1 occurred in the C. cajan alley plots in 2005. The incorporation of $C$. cajan pruning reduced the total exchangeable acidity by $22 \%$ from the preplanting values. This result explained the rise in the $\mathrm{pH}$ of soils of the C. cajan alley plots to $\mathrm{pH} 6.1$ in 2005. Fertilized plots gave the highest total exchangeable acidity of $4.13 \mathrm{c} \mathrm{mol} \mathrm{kg} \mathrm{g}^{-1}$. The use of fertilizer rather raised the total exchangeable acidity by $12 \%$ over the pre-planting. The exchangeable $\mathrm{AI}^{3+}$ decreased over time in all the alley plots. The lowest exchangeable $\mathrm{AI}^{3+}$ occurred in the C. cajan $(0.92 \mathrm{c}$ 
Okonkwo C. I. Mbagwu J. S. C. and Egwua S. O.

mol kg ${ }^{-1}$ ) in 2005. Fertilized and control plots varied in exchange acidity and exchangeable $\mathrm{AI}^{3+}$. Values obtained in 2003 and 2004 were correspondingly higher than that in 2005. In the fertilized plots, the high levels of total exchangeable acidity and exchangeable $\mathrm{A}^{3+}$ could have contributed to the decrease in $\mathrm{pH}$. These results agreed with reports that the application of inorganic fertilizer could alter the chemical properties of soils (Enwezor et a.,, 1990 and Ulluwishwea, 1991).

\section{CONCLUSION}

The results obtained in this study showed that all the treatments applied improved the soil chemical properties over the pre-planting. However, more plant nutrients were gradually built up in the alley cropping system plots than in the fertilizer and control. Therefore the pruning of the legume species incorporated into the soil under the alley cropping system reduced the rate of soil nutrient depletion and increased the productive base of the soil through nutrient released during decomposition of the pruning.

\section{REFERENCES}

Anikwe, M. A.N., C. I Okonkwo and N.L Aniekwe (2000) the effect of changing land use on selected soil properties in the Abakaliki Agroecological zone, south -Eastern Nigeria. Int. J of Environmental Education and information. 10:78-84.

Atta-Krah, A. N, J.E. Sumberg and L. Reynolds, (1996). Leguminous fodder trees in the farming system. An over view of research in the humid tropical zone programme of ILCA in Southwest Nigeria. In Potential of Forage Legumes in Farming Systems of sub-Sahara Africa. Proceeding of a workshop held at ILCA Addis Ababa, Ethiopia

Ayanaba, A. (1975). Toward better use of inoculants in the humid tropics. In Ayanaba, A and P.3 Date (ed.) Biological Nitrogen fixation in farming systems of the Tropics. John Wiley and sons. New York pp 181- 187.

Bouyoucos, G. H. (1951). Hydrometer method improved for making particle size analysis of soils Agron. 1, (54): $465-470$

Bremner, J.M, and C. S. Mulvaney, (1982). Nitrogen total. In: Page A. L., R. H. Miller and D. R. keeney. Methods of soil Analysis. 2. Chemical and Microbiological properties. Agron Monograph no.9 ( $2^{\text {nd }}$ ed.) Madison Wisconsin, USA. American Soc. of Agron, 1324- 1345
Duguma, B. (1983). Early response of four woody fallow legumes grown in acid Ultisol to liming and phosphorus application. IITA, Pub. No. 10: 12-15

Enwezor, W.O., A.C., Oliri, E.E. Opubaribo and E. J. Udoh (1989). A review of Soil Fertility Investigation in S.E. Nigeria. Vol. 11, F.D.A. Lagos. pp 30-39

Enwezor, W.C, A Ohiri, E. E. Opuwaribo and J.E Udo. (1990) Literature Review on soil fertility investigation. In Nigeria fertilizer procurement and distributions divisions (FPDD). Federal ministry of Agriculture and Natural Resources, Lagos

FDALR (1985): Reconnaissance soil survey of Anambra State, Nigeria. Soils Report. FDALR. Kaduna

Gichuru, M. S and B T. Kang, (1990). Callindra calothyrus (meissan) in alley cropping system with sequentially cropped maize and cowpea in southern Nigeria. Agroforestry, 9:191-203

Heanes, D. L (1984). Determination of total organic $\mathrm{C}$ in soils by an improved chromic digestion and spectophotometric procedure. Communication in Soil Science and plant Analysis, 15: 1191-1213.

Hutton, E. M. (1990). Field selection of acid soil tolerant Leucaena from L. leucocephala X. $L$. diversifola crossed in a tropical Oxisol. Tropical Agriculture (Trinidad) 67:1-8

Juo, A. S. R (1983). Selected method for soil and plant Analysis. Manual series, N0 1. Ibadan, Nigeria, IITA.

Kang, B.T. and Ghuman, B.S. (1991). Alley cropping as a sustainable system. In: Moldenhaver, W.C, N.W. Hudson; T.C. Sheria and S. W. Lee (eds.) Development of Conservation farming on hillslopes. Soil and Water Conservation Society Ankeny, Iowa, USA

Kang, B.T,L Reynolds and A.N. Atta - krah, (1990). Alley farming. Adv. Agron. 43: 315 - 359.

Kang, B.T, and G. F. Wilson. (1987). The development of alley cropping as a promising agroforestry technology. In: Steppler, H.A. and P.K.R. Nair (eds.) Agroforestry.: A Decade of Development Nairobi, Kenya: ICRAF

Larsen, S. (1995). Soil phosphorus. Adv. In Agron, 19: 151-210.

Landon, J.R. (1991). Booker Tropical Soil Manual. A hand book for Soil Survey and Agricultural land evaluation in the Tropics and sub-tropics. John Wiley and sons inc. 605 Third Avenue, New York, USA.

ODNRI. (1989). Nigeria profile of Agriculture potential ODA (United Kingdom). 10-13 
Olsen, S.R. and L.E. Sommers, (1982). Phosphorus. In: Page, A.L, R. H. Miller, and D. R. Keeney. Methods of Soil Analysis. 2.

Chemical and Microbiological properties. Agron. Monograph no. 9 (end ed.) Madison, Wisconsin, USA. America Soc. of Agron pp. 1471-1483

Sangniga, N., C.D. Bower and S.K.A, Danso, (1990b). Assessment of genetic variability for $\mathrm{N}_{2}$-fixation between and within provenance of Leucaena leucocephala and Acacia abida estimated by ${ }^{15} \mathrm{~N}$ labeling technique. Plant and soil. 127: 109-178.

SAS (1985).SAS User Guide, Statistical Analysis Systems Institute Inc. cary: pp. 25-36
Tel. D. and P. Rao, 1982 Automated and SemiAutomated Methods for Soil and Plant Analysis. IITA Manual Series N0: 7.

Ulluwishewa, R. (1991). Soil fertility management of paddy fields by traditional farmers in the dry zone of Sri Lanka. J. of Sustainable Agriculture. 1, 95-106.

USDA-SCS (1974). Definitions and Abbreviations for Soil Description. West Technical Service Centre, Portland, Oregon, USA. Pp. 806-914

Young, A. (1989). Agroforestry for Soil Conservation. Wallingford. UK: CAB International: pp 213-227 